\title{
Targeting and treatment of glioblastomas with human mesenchymal stem cells carrying ferrociphenol lipid nanocapsules
}

This article was published in the following Dove Press journal:

International Journal of Nanomedicine

12 February 2015

Number of times this article has been viewed

\author{
Anne Clavreul' \\ Angélique Montagu ${ }^{2}$ \\ Anne-Laure Lainé ${ }^{2}$ \\ Clément Tétaud ${ }^{2}$ \\ Nolwenn Lautram ${ }^{2}$ \\ Florence Franconi ${ }^{3}$ \\ Catherine Passirani ${ }^{2}$ \\ Anne Vessières ${ }^{4}$ \\ Claudia N Montero-Menei ${ }^{2}$ \\ Philippe Menei' \\ 'Département de Neurochirurgie, \\ Centre Hospitalier Universitaire, \\ Angers, France; ' ${ }^{2}$ NSERM UMR-S \\ 1066, Université d'Angers, LUNAM \\ Université, Angers, France; ${ }^{3} \mathrm{CIFAB}$ - \\ PRIMEX, Université d'Angers, LUNAM \\ Université, Angers, France; ${ }^{4} \mathrm{CNRS}$ - \\ UMR 7223, ENSCP, Paris, France
}

Correspondence: Anne Clavreul INSERM UI 066, Micro et

Nanomédecines Biomimétiques (MINT),

4 rue Larrey, 49933 Angers, France

Tel +3324468 8548

Fax +3324468 8546

Email anne.clavreul@univ-angers.fr

\begin{abstract}
Recently developed drug delivery nanosystems, such as lipid nanocapsules (LNCs), hold great promise for the treatment of glioblastomas (GBs). In this study, we used a subpopulation of human mesenchymal stem cells, "marrow-isolated adult multilineage inducible" (MIAMI) cells, which have endogenous tumor-homing activity, to deliver LNCs containing an organometallic complex (ferrociphenol or Fc-diOH), in the orthotopic U87MG GB model. We determined the optimal dose of Fc-diOH-LNCs that can be carried by MIAMI cells and compared the efficacy of Fc-diOH-LNC-loaded MIAMI cells with that of the free-standing Fc-diOH-LNC system. We showed that MIAMI cells entrapped an optimal dose of about $20 \mathrm{pg}$ Fc-diOH per cell, with no effect on cell viability or migration capacity. The survival of U87MG-bearing mice was longer after the intratumoral injection of Fc-diOH-LNC-loaded MIAMI cells than after the injection of Fc-diOH-LNCs alone. The greater effect of the Fc-diOH-LNC-loaded MIAMI cells may be accounted for by their peritumoral distribution and a longer residence time of the drug within the tumor. These results confirm the potential of combinations of stem cell therapy and nanotechnology to improve the local tissue distribution of anticancer drugs in GB.
\end{abstract}

Keywords: glioblastoma, mesenchymal stem cells, nanoparticle, drug delivery, targeting

\section{Introduction}

Glioblastomas (GBs) are the most common, invasive, and aggressive primary brain tumors in humans, affected patients having a median survival of only 14.6 months. ${ }^{1,2}$ The inefficacy of current standard therapies arises partly from the poor intratumoral distribution of treatment agents and an inability to target tumor cells, such as GB stem cells, migrating away from the main tumor mass and causing local recurrences. ${ }^{3} \mathrm{New}$ strategies are therefore urgently required, to improve tumor drug distribution and target disseminated tumor cells, while sparing normal cells.

We recently developed a new GB-targeting therapeutic strategy based on the use of mesenchymal stem cells (MSCs) as cellular carriers of drug-loaded lipid nanocapsules (LNCs). ${ }^{4-6}$ In particular, we used a homogeneous and immature subpopulation of human MSCs called "marrow-isolated adult multilineage inducible" (MIAMI) cells. ${ }^{7,8}$ These cells, which are easily obtained from the bone marrow of patients, possess a unique molecular phenotype and their populations can be repeatedly doubled for expansion purposes, without a loss of stem cell properties. They have been successfully used for cell-based brain treatments. ${ }^{9-11}$ Like other MSCs, MIAMI cells have endogenous tumor-homing activity and are found throughout the peritumoral zone after their injection directly into the tumor or into the contralateral brain hemisphere, in mice bearing U87MG GB. ${ }^{12-14}$ This peritumoral distribution of MIAMI cells may contribute 
to tumor stroma remodeling. Strong antitumor effects have been reported in experimental glioma models, following the intracranial administration of MSCs genetically modified by viruses conferring the expression of immunostimulators or toxic molecules. ${ }^{5,15-17}$ We overcame the need to work with viruses, by using nanoparticles as LNCs. These particles have several advantages over viral vectors, including a low risk of immunogenicity, ease of production without high manufacturing costs, and the possibility of transporting multiple types of therapeutic agents, including drugs, ${ }^{18,19}$ radionuclides, ${ }^{20}$ DNA, ${ }^{21}$ small interfering ribonucleic acid, ${ }^{22}$ and nucleaseresistant locked nucleic acids. ${ }^{23}$ LNCs accumulate rapidly within cells without the need for transfection agents, and they can bypass the endolysosomal compartment and overcome the multidrug-resistance mechanism. ${ }^{24,25}$ In previous studies, we encapsulated an organometallic complex analog of 4-hydroxytamoxifen called ferrociphenol (Fc-diOH) in LNCs. Fc-diOH was developed by adding a ferrocene moiety to the tamoxifen skeleton. ${ }^{26}$ The resulting Fc-diOH-LNCs were shown to be promising for therapeutic purposes in the $9 \mathrm{~L}$ rat brain tumor model. ${ }^{27-29}$ The precise mechanism underlying Fc-diOH cytotoxicity is not fully understood. It has been suggested that the metabolic oxidation of $\mathrm{Fc}$-diOH produces electrophilic quinone methide metabolites within the cell that may be, at least partly, associated with cell cycle arrest and senescence. ${ }^{30}$ We recently showed that MIAMI cells took up Fc-diOH-LNCs efficiently and that this internalization did not induce MIAMI cell death. ${ }^{6}$ Furthermore, Fc-diOH-LNCloaded MIAMI cells had a cytotoxic effect on human U87MG GB cells in vitro and in vivo after their intratumoral injection in the heterotopic U87MG GB model in nude mice. ${ }^{6}$

The objective of this study was to obtain proof-of-concept that the combination of Fc-diOH-LNCs with MIAMI cells facilitates the specific targeting of brain tumors and ensures an extensive intratumoral distribution of this delivery device in the orthotopic U87MG GB model. We first determined the optimal dose of Fc-diOH-LNCs that can be carried by MIAMI cells with no significant loss of viability and migration capacity. We then determined the amount of the drug present within the MIAMI cells by liquid chromatography-tandem mass spectrometry (LC-MS/MS), and compared the efficacy of Fc-diOH-LNC-loaded MIAMI cells with that of Fc-diOHLNCs alone in the orthotopic U87MG GB model.

\section{Materials and methods Chemical materials}

Fc-diOH (2-ferrocenyl-1,1-bis[4-hydroxyphenyl]-but-1ene) was prepared by McMurry coupling. ${ }^{31}$ The lipophilic
Labrafac $^{\circledR}$ WL1349 (caprylic-capric acid triglycerides) was purchased from Gattefosse S.A. (Saint-Priest, France). Lipoïd $^{\circledR}$ S75-3 (soybean lecithin with 69\% phosphatidylcholine) and Solutol ${ }^{\circledR}$ HS15 (a mixture of free polyethylene glycol 660 and polyethylene glycol 660 hydroxystearate) were obtained from Lipoïd Gmbh and BASF (Ludwigshafen, Germany), respectively. $\mathrm{NaCl}$ was obtained from Prolabo (Fontenay-sous-Bois, France). Deionized water was obtained with the Milli-Q Plus system (Merck Millipore, Molsheim, France).

\section{Fc-diOH-loaded LNCs}

As previously described, ${ }^{6}$ LNCs were prepared by the phaseinversion temperature method (Figure 1). Briefly, Solutol ${ }^{\circledR}$ HS15 (9.7\% w/w), Lipoïd ${ }^{\circledR}$ S75-3 (1.5\% w/w), Labrafac ${ }^{\circledR}$ $\mathrm{WL} 1349$ (24.2\% w/w), $\mathrm{NaCl}(1.8 \% \mathrm{w} / \mathrm{w})$, and water $(62.8 \%$ $\mathrm{w} / \mathrm{w})$ were mixed and heated to $95^{\circ} \mathrm{C}$ with constant stirring (magnetic stirrer). The mixture underwent three cycles of progressive heating and cooling between $95^{\circ} \mathrm{C}$ and $60^{\circ} \mathrm{C}$, and was then subjected to an irreversible shock induced by the addition of deionized water $(71.4 \%, \mathrm{w} / \mathrm{w})$ at $2^{\circ} \mathrm{C}$ to the mixture at $70^{\circ} \mathrm{C}$. Finally, the LNCs were sterilized by passage through a filter with $0.2 \mu \mathrm{m}$ pores. For the formulation of Fc-diOH-LNCs, Fc-diOH was added, as a powder $(2.1 \%$, $\mathrm{w} / \mathrm{w})$, to the LNC excipients, to prepare a suspension of FcdiOH-LNCs at a concentration of $6 \mathrm{mg}$ of $\mathrm{Fc}$-diOH per $\mathrm{g}$ of LNC suspension (14 mM).

\section{LNC characterization}

As previously described, ${ }^{6}$ drug loading was assessed by spectrophotometry at $450 \mathrm{~nm}$ after dilution $(1: 10)$ in a 22/67/11 (v/v/v) ethanol/tetrahydrofuran/water mixture. Size, polydispersity index, and charge distribution were determined by dynamic light scattering analysis with a Zetasizer ${ }^{\circledR}$ Nano Series DTS 1060 (Malvern Instruments, Malvern, UK). The LNCs were diluted 1:60 (v/v) in deionized water for this evaluation.

\section{Cell culture}

MIAMI cells were obtained from iliac crest aspirates from a human male postmortem organ donor (protocol agreed by the French Agency of Biomedicine) and were isolated as previously described. ${ }^{7,12}$ This cell population was expanded in Dulbecco's Modified Eagle's Medium (DMEM) low-glucose medium (DMEM-LG; Thermo Fisher Scientific, Waltham, MA, USA) containing 3\% fetal bovine serum (FBS) (GE Healthcare Life Sciences, Utah, USA) and 1\% antibiotic and antimycotic solution (Sigma-Aldrich Co., St Louis, MO, USA), on a fibronectin substrate $(10 \mathrm{ng} / \mathrm{mL}$, Sigma-Aldrich 


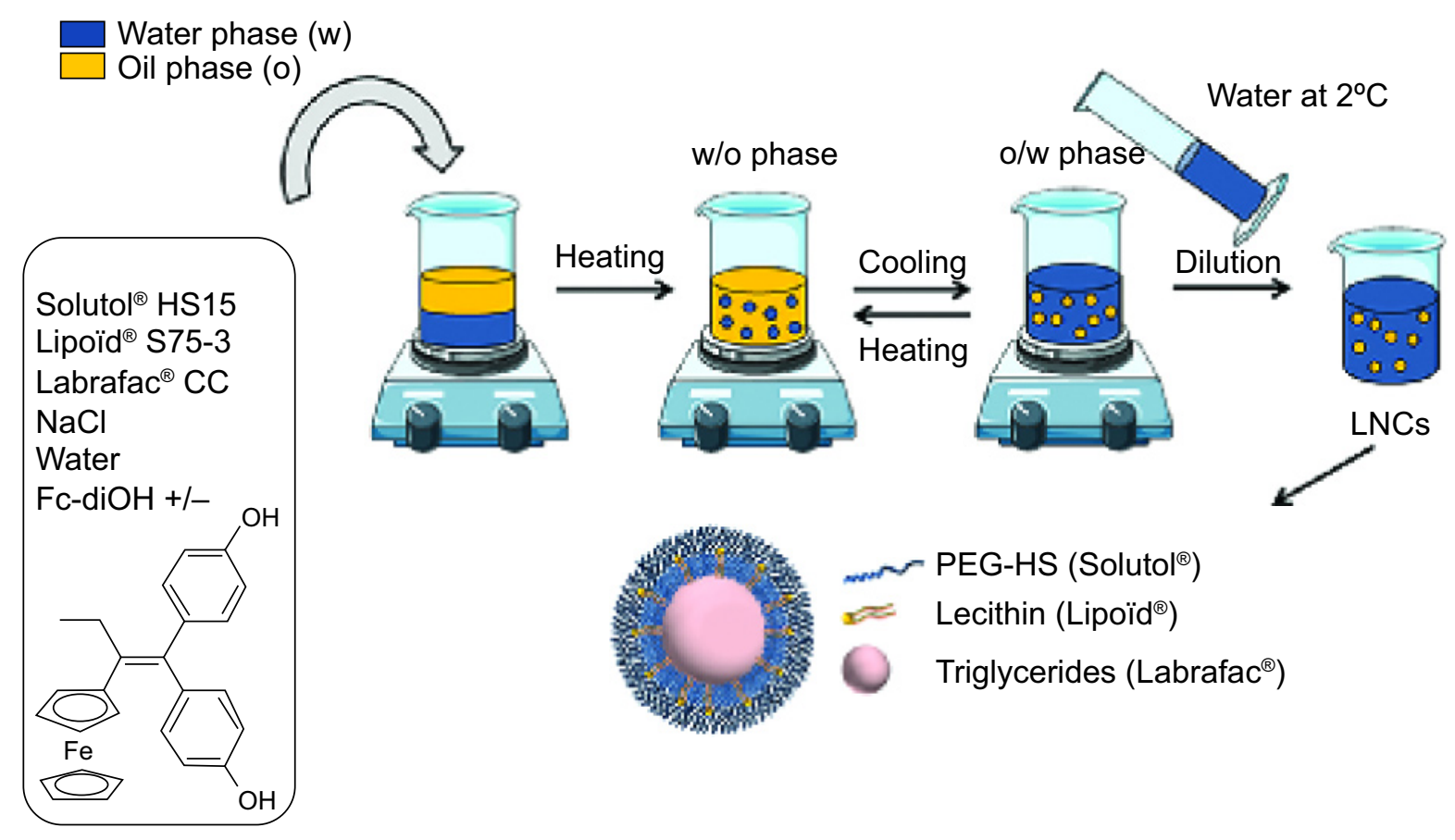

Figure I Preparation of LNCs by the phase-inversion temperature method.

Notes: Solutol ${ }^{\circledR}$ HSI5, Lipoïd Gmbh AS (Ludwigshafen, Germany); Lipoïd ${ }^{\circledR}$ S75-3, Lipoïd Gmbh (Ludwigshafen, Germany) AS; Labrafac ${ }^{\circledR}$ WLI349, Gattefosse S.A. (SaintPriest, France).

Abbreviations: LNCs, lipid nanocapsules; Fc-diOH, ferrociphenol; PEG-HS, polyethylene glycol-hydroxystearate.

Co.) in a humidified incubator at $37^{\circ} \mathrm{C}$, under an atmosphere containing $3 \% \mathrm{O}_{2} / 5 \% \mathrm{CO}_{2} / 92 \% \mathrm{~N}_{2}$. The cells were grown to $40 \%$ confluence. All experiments were performed with cells between passages 4 and 5 .

The human U87MG GB cell line was obtained from the (American Type Culture Collection, Manassas, VA, USA). Cells were maintained in DMEM-high glucose medium (DMEM-HG; Lonza, Verviers, Belgium) containing 10\% fetal bovine serum (Lonza) and 1\% antibiotics (SigmaAldrich Co.), under an atmosphere containing 5\% $\mathrm{CO}_{2}$ $\left(37^{\circ} \mathrm{C}\right)$, in a humidified incubator, until they reached $80 \%$ confluence.

\section{Cell viability}

MIAMI or U87MG cells were plated in 96-well plates at densities of $2 \times 10^{4}$ cells $/ \mathrm{cm}^{2}$ and $1 \times 10^{4}$ cells $/ \mathrm{cm}^{2}$, respectively. After 48 hours, the culture medium was removed and cells were treated with free Fc-diOH or Fc-diOH-LNCs at concentrations of 0.01 to $100 \mu \mathrm{M}$. Unloaded (blank) LNCs were also tested with the same excipient concentration as for Fc-diOH-LNCs. After 72 hours, the medium was removed from the wells and the plates were stored at $-80^{\circ} \mathrm{C}$ until the assays were carried out. Cell survival was estimated with the CyQUANT ${ }^{\circledR}$ cell proliferation assay kit, according to the manufacturer's instructions (Thermo Fisher Scientific).

\section{Preparation of Fc-diOH-LNC-loaded MIAMI cells}

MIAMI cells $\left(3 \times 10^{5}\right.$ to $4 \times 10^{5}$ cells $)$ were incubated for 1 hour at $37^{\circ} \mathrm{C}$ with $1 \mathrm{mg} / \mathrm{mL}$ blank LNCs or with Fc-diOH-LNCs, corresponding to a dose of $120 \mu \mathrm{M}$ Fc-diOH in Hank's balanced salt solution (HBSS), with $\mathrm{Ca}^{2+}$ and $\mathrm{Mg}^{2+}$ (Lonza). At the end of the incubation period, cells were washed twice with HBSS, counted, and used for in vitro and in vivo experiments, as described below.

\section{Fc-diOH analysis by LC/MS-MS}

MIAMI cells loaded with Fc-diOH-LNCs were resuspended in $600 \mu \mathrm{L}$ of a 1:1 (v/v) mixture of water and methanol and were placed in an ultrasonic bath for 2 minutes. The cells were then pelleted by centrifugation and the supernatant was filtered through Oasis HLB 96-well $\mu$ Elution Plates, 2 mg sorbent per well, with a particle size of 30 microns (Waters Corporation, Milford, MA, USA). Fc-diOH was eluted in $200 \mu \mathrm{L}$ of methanol.

Chromatography was performed with the Waters Alliance $^{\circledR} 2695$ system (Waters Corporation), with an Uptisphere ${ }^{\circledR}$ C18 ODB $150 \mathrm{~mm} \times 2 \mathrm{~mm}, 5 \mu \mathrm{m}$ column (Interchim, Montluçon, France). The mobile phase consisted of various combinations of phase A (water) and phase B (acetonitrile). The mobile phase initially consisted of $50 \%$ A and $50 \% \mathrm{~B}$; a linear gradient was then applied, to reach a composition 
of $100 \%$ B after 5 minutes. The original composition of the mobile phase was then restored over a period of 1 minute, and maintained for 6 minutes. The column temperature was set at $30^{\circ} \mathrm{C}$ and the flow rate was $0.3 \mathrm{~mL} / \mathrm{minute}$. The total high-performance liquid chromatography effluent was analyzed in a Quattro ${ }^{\circledR}$ Micro triple quadruple mass spectrometer (Waters Corporation). Ionization was achieved by electrospray, in positive-ion mode. The mass spectrometer was operate in multiple reaction monitoring mode with collision energy of 32 electron-volts. The transition monitored was mass-to-charge ratio $\mathrm{m} / \mathrm{z} 423.7 \rightarrow 358.9$ for Fc-diOH. A typical retention time for $\mathrm{Fc}-\mathrm{diOH}$ was 7.32 minutes. Quantification was achieved with QuanLynx ${ }^{\circledR}$ (Waters Corporation), by comparing the observed peak area ratios of Fc-diOH samples with a calibration curve obtained under the same experimental conditions. The range of the linear response was large, extending from 0 to $50 \mathrm{ng} / \mathrm{mL}$.

\section{In vitro toxicity of Fc-diOH-LNC-loaded MIAMI cells to U87MG cells}

We assessed the in vitro toxicity of Fc-diOH-LNC-loaded MIAMI cells to U87MG cells, by performing coculture experiments in Transwell plates containing inserts with a pore size of $0.4 \mu \mathrm{m}$ (Merck Millipore). The U87MG cells $\left(5 \times 10^{3}\right.$ cells $\left./ \mathrm{cm}^{2}\right)$ were plated in the lower compartment. After 48 hours, Fc-diOH-LNCs $(0.03-3 \mu \mathrm{g})$ and MIAMI cells $\left(5 \times 10^{3}\right.$ or $\left.40 \times 10^{3}\right)$ loaded with blank or Fc-diOH-loaded LNCs were added to the upper compartment. Four days later, the inserts were removed and a CyQUANT ${ }^{\circledR}$ cell proliferation assay was performed as described above.

\section{Migration assay}

Transwell inserts (Millicell ${ }^{\circledR}$ cell culture inserts, $8 \mu \mathrm{m}$ pore size; Merck Millipore) were used to assess the migration of unloaded and Fc-diOH-LNC-loaded MIAMI cells in response to factors secreted by U87MG cells. The U87MG cells were grown to $70 \%$ to $80 \%$ confluence in DMEM-HG containing $10 \%$ FBS and $1 \%$ antibiotics. The medium was replaced by DMEM supplemented with $0.1 \%$ bovine serum albumin (BSA) and $0.2 \%$ antibiotics and the cells were cultured for 24 hours. The resulting conditioned medium (CM) was centrifuged and stored at $-20^{\circ} \mathrm{C}$ for subsequent use. For migration experiments, unloaded and Fc-diOH-LNC-loaded MIAMI cells $\left(1.5 \times 10^{4}\right)$ were added to the upper chamber, and $500 \mu \mathrm{L}$ of control medium (DMEM with $0.1 \%$ BSA and $0.2 \%$ antibiotics) or U87MG CM was added to the bottom chamber. After 4 hours, the cells that had migrated to the underside of the insert membrane were stained with hematoxylin and counted under a microscope.

\section{In vivo experiments}

Eight week old female athymic Swiss nude mice were obtained from Charles River (L'Arbresle, France). Experiments were conducted in accordance with the regulations of the French Ministry of Agriculture and the European Communities Council Directive of 24 November 1986 (86/609/ EEC). Animals were anesthetized by an intraperitoneal injection of xylazine (13 mg/kg body weight) and ketamine (100 mg/kg body weight) and were positioned in a Kopf stereotaxic instrument.

On day 0 , we injected $3 \times 10^{4}$ U87MG cells in $5 \mu \mathrm{L}$ HBSS with $\mathrm{Ca}^{2+}$ and $\mathrm{Mg}^{2+}$ into the striatum of mice (coordinates: 2.1 $\mathrm{mm}$ lateral to the bregma, $0.5 \mathrm{~mm}$ anterior and $3 \mathrm{~mm}$ interior to the outer border of the cranium). On day 6 , the mice were assigned to three groups receiving an injection, at the same coordinates, of a) HBSS with $\mathrm{Ca}^{2+}$ and $\mathrm{Mg}^{2+}$; b) Fc-diOHLNCs; c) Fc-diOH-LNC-loaded MIAMI cells. For analysis of the effects of treatment on tumor growth, we measured tumor volume by magnetic resonance imaging (MRI) on day 20 and the mice were killed when they had lost more than $10 \%$ of their body weight. For analysis of the distribution of MIAMI cells loaded with Fc-diOH-LNCs, mice were killed on day 13 . Brains were snap-frozen in isopentane cooled by liquid nitrogen and stored at $-80^{\circ} \mathrm{C}$. Coronal sections of the brain were cut at $10 \mu \mathrm{m}$ intervals and collected on silanetreated slides.

\section{MRI}

Mice were scanned with a Bruker Biospec 70/20 machine operating with a $7 \mathrm{~T}$ magnetic field (Bruker BioSpin SA, Wissembourg, France) and equipped with a $1 \mathrm{H}$ cryoprobe, under isoflurane anesthesia $\left(1.5 \%-0.5 \%, \mathrm{O}_{2}: 0.5 \mathrm{~L} /\right.$ minute $)$, to assess tumor development. Mouse body temperature was maintained at $36.5^{\circ} \mathrm{C}-37.5^{\circ} \mathrm{C}$ with a feedback-regulated heating pad for the entire imaging protocol. Rapid anatomical proton images were obtained with a rapid acquisition with relaxation enhancement sequence (repetition time $=3,200 \mathrm{~ms}$; mean echo time $=21.3 \mathrm{~ms}$; rapid acquisition with relaxation enhancement factor $=4$; field of view $=2 \times 2 \mathrm{~cm}$; matrix $256 \times 256$; eleven contiguous slices of $0.5 \mathrm{~mm}$, number of excitations $=1$ ).

\section{Immunofluorescence}

Cryosections were air-dried, rehydrated in phosphate buffered saline and fixed by incubation for 10 minutes in $4 \%$ paraformaldehyde $\mathrm{pH} 7.4$ at $4{ }^{\circ} \mathrm{C}$. Nonspecific binding was blocked by incubating the sections in 4\% BSA and $10 \%$ normal goat serum in phosphate buffered saline. The 
sections were incubated overnight, at $4^{\circ} \mathrm{C}$, with isotype controls and primary antibodies against endothelial cells (mouse CD31; BD Biosciences, San Jose, CA, USA) and proliferative cells (Ki67; Dako Denmark A/S, Glostrup, Denmark). The primary antibodies were detected with biotinylated secondary antibodies and the signal was amplified with streptavidin-fluorescein isothiocyanate (Dako Denmark A/S). Nuclei were counterstained with 4',6-diamidino-2phenylindole (Sigma-Aldrich Co.). Cryosections of three mice from each of the groups described above ( $a, b$, and c) were analyzed under a fluorescence microscope (Axioscope $^{\circledR} 2$ light microscope; Carl Zeiss Meditec AG, Jena, Germany). Counts of $\mathrm{CD} 31^{+}$vessels or $\mathrm{Ki} 67^{+}$cells were carried out on six cryosections per mouse, corresponding to the central and peripheral portions of the tumor, with the MetaView computerized image-analysis system (Roper Scientific, Evry, France). Two fields per cryosection, at a magnification of $\times 200$, were randomly selected for the tumor. Results are expressed as the mean number of $\mathrm{Ki}^{+}$ cells or $\mathrm{CD} 1^{+}$vessels per $\mathrm{mm}^{2} \pm$ standard error of the mean (SEM), for each group.

\section{Fluorescence in situ hybridization}

MIAMI cells loaded with Fc-diOH-LNCs were detected in tumor cryosections by fluorescence in situ hybridization, with a human Y-chromosome probe, as previously described. ${ }^{4}$ The DNA probe was complementary to the highly repetitive human satellite III sequences located close to the centromeric region of the human Y-chromosome DYZ1 locus (CEPY) and was labeled with the SpectrumOrange fluorochrome (Vysis; Abbott Laboratories, Abbott Park, IL, USA). Cryosections were then analyzed under an Axioscope ${ }^{\circledR} 2$ fluorescence microscope.

\section{Statistical analysis}

Results are expressed as means \pm SEM. Statistical analyses were performed with the Mann-Whitney $U$-test. Survival advantage was analyzed by log-rank tests, based on the Kaplan-Meier method. Differences were considered significant if the $P$-value was $<0.05$.

\section{Results}

\section{Physicochemical properties of Fc-diOH- LNCs}

The physicochemical characteristics of blank LNCs and Fc-diOH-loaded LNCs (particle size, polydispersity index, and zeta potential) are presented in Table 1. Blank and Fc-diOH-loaded LNCs formulated by the phase-inversion temperature method had mean diameters of $97.3 \pm 3.9 \mathrm{~nm}$ and $81 \pm 0.6 \mathrm{~nm}$, respectively, and a polydispersity index of less than 0.1 , indicating a narrow size distribution. In all cases, the zeta potential was slightly negative. The Fc-diOH-LNCs were loaded with $5.90 \pm 0.22 \mathrm{mg} \mathrm{Fc}-\mathrm{diOH}$ per $\mathrm{mL}$ of LNC suspension.

\section{Effect of Fc-diOH-loaded LNCs on U87MG and MIAMI cells}

We investigated the cytotoxicity of Fc-diOH-LNCs in U87MG and MIAMI cells. The cell survival profiles after 3 days of treatment with Fc-diOH, blank LNCs, and Fc-diOH-loaded LNCs are presented in Figure 2. At low concentrations $(0.01-0.1 \mu \mathrm{M})$, neither free $\mathrm{Fc}-\mathrm{diOH}$ nor Fc-diOH-loaded LNCs altered the growth of U87MG cells (Figure 2A). U87MG cell survival was decreased by treatment with $1 \mu \mathrm{M}$ Fc-diOH, reaching approximately 50\% inhibition $\left(\mathrm{IC}_{50}\right)$ at $6 \mu \mathrm{M}$ for free $\mathrm{Fc}-\mathrm{diOH}$ and $1 \mu \mathrm{M}$ for $\mathrm{Fc}-$ diOH-LNCs. MIAMI cell viability was not affected by the concentration of Fc-diOH-loaded LNCs used (Figure 2B). Only free Fc-diOH caused the death of MIAMI cells (about $70 \%$ cell death at $100 \mu \mathrm{M})$. No change in the viability of U87MG and MIAMI cells was observed in the presence of blank LNCs at the concentrations tested (Figure 2).

\section{Optimization and quantification of Fc-diOH internalization by MIAMI cells}

We previously showed that MIAMI cells could take up LNCs without the need for transfection agents and that LNC uptake was concentration- and time-dependent. ${ }^{4}$ In this work, we defined the optimal dose of Fc-diOHLNCs that MIAMI cells could carry without deleterious effects on viability for at least 7 days after their uptake.

Table I Physicochemical characteristics of blank LNCs and Fc-diOH-LNCs (mean of four samples \pm SEM)

\begin{tabular}{lllll}
\hline LNCs & Mean particle size $(\mathbf{n m})$ & PDI & Zeta potential $(\mathbf{m V})$ & Fc-diOH loading $(\mathbf{m g} / \mathbf{m L})$ \\
\hline Blank LNCs & $97.25 \pm 3.86$ & $0.05 \pm 0.01$ & $-10.93 \pm 0.45$ & - \\
Fc-diOH-LNCs & $81 \pm 0.58$ & $0.04 \pm 0.01$ & $-10.58 \pm 1.19$ & $5.90 \pm 0.22$ \\
\hline
\end{tabular}

Abbreviations: LNCs, lipid nanocapsules; Fc-diOH, ferrociphenol; Fc-diOH-LNCs, ferrociphenol lipid nanocapsules; SEM, standard error of the mean; PDI, polydispersity index. 
A

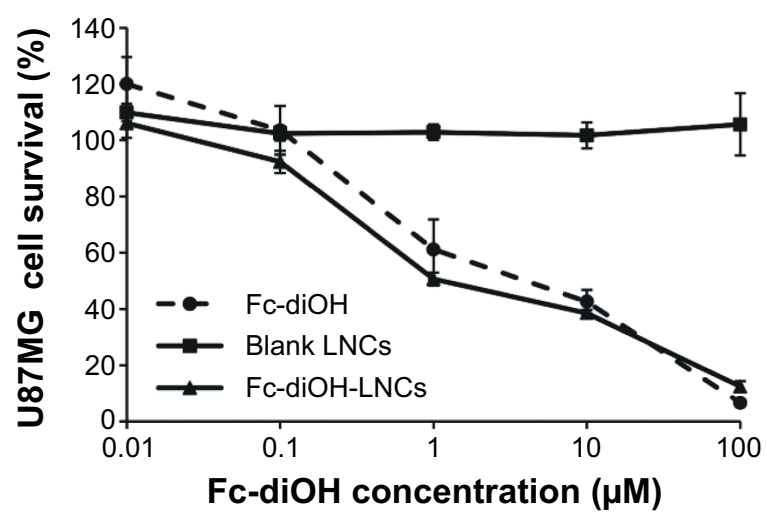

B

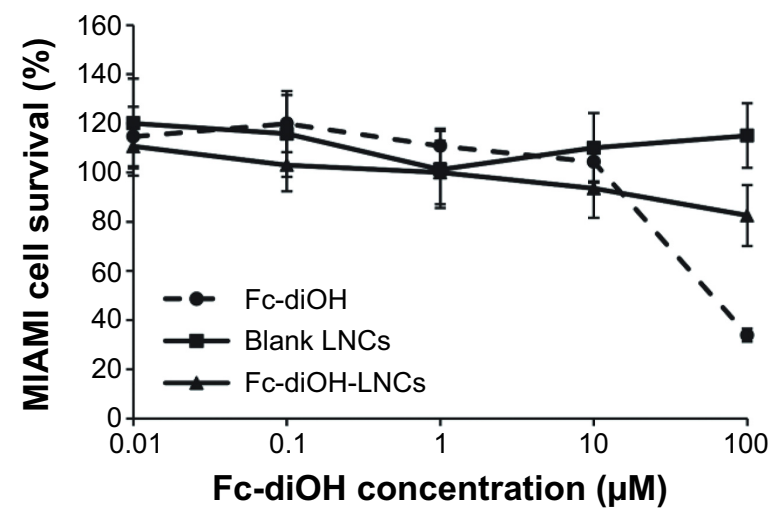

Figure 2 Cell viability following the exposure of U87MG (A) and MIAMI cells (B) to various concentrations of Fc-diOH, blank LNCs or Fc-diOH-LNCs $(0.0 \mathrm{I}-\mathrm{I00} \mu \mathrm{M})$. Notes: Data are expressed as the mean \pm SEM $(n=3)$. The results obtained for U87MG cells or MIAMI cells cultured with culture medium alone were considered to correspond to $100 \%$ survival.

Abbreviations: LNCs, lipid nanocapsules; Fc-diOH, ferrociphenol; MIAMI, marrow-isolated adult multilineage inducible; SEM, standard error of the mean.

For this purpose, we had to take drug and LNC matrix component concentrations into account. The incubation of MIAMI cells for 1 hour at $37^{\circ} \mathrm{C}$ with $2 \mathrm{mg} / \mathrm{mL}$ blank LNCs resulted in a $30 \%$ loss of cell viability 7 days after uptake, whereas $80 \%$ of MIAMI cells remained viable when incubated with $1 \mathrm{mg} / \mathrm{mL}$ blank LNCs (Figure S1). Furthermore, we found that the concentration of Fc-diOHloaded LNCs should not exceed $120 \mu \mathrm{M}$, to ensure a MIAMI cell viability of $80 \%$ (Figure $\mathrm{S} 1$ ). The conditions for Fc-diOH-LNC internalization were therefore set as follows: $1 \mathrm{mg} / \mathrm{mL} \mathrm{LNC}$ matrix components and $120 \mu \mathrm{M}$ $\mathrm{Fc}$-diOH for 1 hour at $37^{\circ} \mathrm{C}$.

In these conditions, LC-MS/MS analysis showed that $40 \times 10^{3} \mathrm{Fc}$-diOH-LNC-loaded MIAMI cells corresponded to $814.5 \pm 97.7 \mathrm{ng}$ of drug (about $20 \mathrm{pg} \mathrm{Fc}$-diOH per cell). This dose was confirmed in a cytotoxicity assay on U87MG cells (Figure 3). U87MG cells were plated at the bottom of culture wells and upper Transwells were seeded with either blank LNC-loaded MIAMI cells or Fc-diOH-LNCloaded MIAMI cells (Figure 3A). This Transwell system allowed the passage of LNCs, but not of cells. We found that $40 \times 10^{3} \mathrm{Fc}$-diOH-LNC-loaded MIAMI cells decreased U87MG cell survival by $35 \%$, whereas $40 \times 10^{3}$ blank LNCloaded MIAMI cells had no effect on U87MG cell viability (Figure 3B). This decrease in survival is intermediate between those induced by $0.3 \mu \mathrm{g}$ and $3 \mu \mathrm{g}$ of $\mathrm{Fc}$-diOHLNCs: $30 \%$ and $50 \%$, respectively. These findings confirm that $40 \times 10^{3} \mathrm{Fc}$-diOH-LNC-loaded MIAMI cells correspond to about $800 \mathrm{ng}$ of $\mathrm{Fc}$-diOH. We also checked the viability of the blank and Fc-diOH-LNC-loaded MIAMI cells in the upper Transwells. Similar numbers of blank and Fc-diOHLNC-loaded MIAMI cells were present in the Transwells after 96 hours, suggesting that Fc-diOH-LNC uptake had no effect on the viability of MIAMI cells in the Transwells, over this time period at least (Figure 3C). Thus, the release of Fc-diOH-LNCs or Fc-diOH was not induced by the death of MIAMI cells.

\section{Analysis of Fc-diOH-LNC-loaded MIAMI cell migration toward U87MG cells}

One of the major challenges in the development of the MIAMI cell-LNC system is the preservation of carrier migration for the delivery of toxic compounds to areas of the tumor in a specific manner. We showed, in a Transwell migration assay, that almost no Fc-diOH-LNC-loaded MIAMI cells migrated toward the control medium, whereas about $30 \%$ of these cells migrated toward the U87MG CM (Figure 4A, B). Similar proportions of cells migrating toward these media were observed for unloaded MIAMI cells (Figure 4B). These in vitro results were confirmed in vivo because, 7 days after their injection into the U87MG tumor, a few Fc-diOH-LNC-loaded MIAMI cells were found within the tumor, whereas most were found around the tumor mass (Figure 4C, D). A similar intratumoral distribution of MIAMI cells has also been reported for unloaded MIAMI cells. ${ }^{12}$

\section{In vivo toxicity of Fc-diOH-LNC-loaded MIAMI cells to U87MG cells}

We previously showed that the injection of MIAMI cells did not affect the survival of U87MG-bearing mice in the heterotopic and orthotopic models. ${ }^{6}{ }^{12}$ In this study, we aimed to demonstrate the utility of these cells for the efficient delivery of Fc-diOH-LNCs to an intracerebral tumor. We therefore 


\section{A}

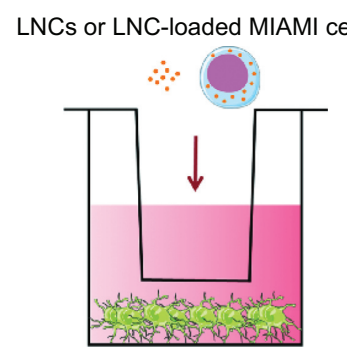

U87MG cells
B

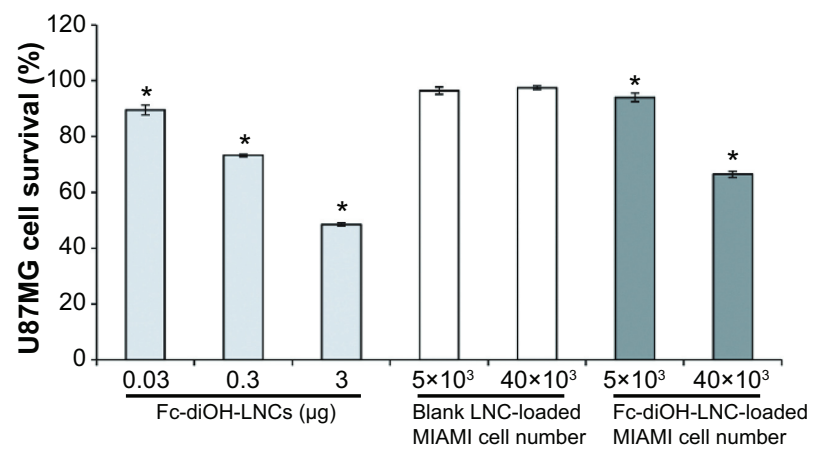

C

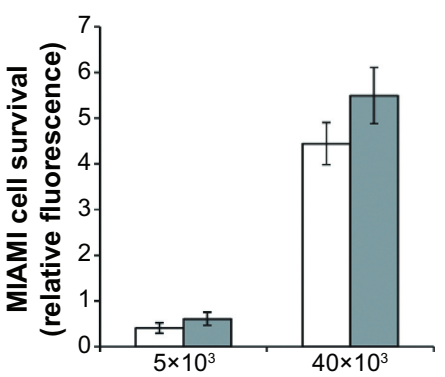

$\square$ Blank LNC-loaded MIAMI cells $\square$ Fc-diOH-LNC-loaded MIAMI cells

Figure 3 In vitro toxicity of Fc-diOH-LNCs and Fc-diOH-LNC-loaded MIAMI cells to U87MG cells.

Notes: (A) Schematic diagram of the principle of coculture experiments to assess the cytotoxicity to U87MG cells of Fc-diOH-LNCs or Fc-diOH-LNC-loaded MIAMI cells. The pore size of the insert $(0.4 \mu \mathrm{m})$ allowed the passage of LNCs. (B) Viability of U87MG cells following exposure to Fc-diOH-LNCs (0.03-3 $\mu \mathrm{g})$ or MIAMI cells loaded with blank LNCs or Fc-diOH-LNCs. Two doses of MIAMI cells were tested: $5 \times 10^{3}$ and $40 \times 10^{3}$ cells, corresponding to Fc-diOH doses of about $0.1 \mu \mathrm{g}$ and $0.8 \mu \mathrm{g}$, respectively. The results obtained for U87MG cells cultured with culture medium alone were considered to correspond to $100 \%$ survival. Data are expressed as the mean of three wells \pm SEM $(\mathrm{n}=2)(* \mathrm{P}<0.05$, versus U87MG cells cultured with culture medium alone). (C) Viability of MIAMI cells loaded with blank LNCs or Fc-diOH-LNCs 4 days after their addition to the upper compartment of the Transwell system.

Abbreviations: LNCs, lipid nanocapsules; Fc-diOH, ferrociphenol; MIAMI, marrow-isolated adult multilineage inducible; SEM, standard error of the mean.

A

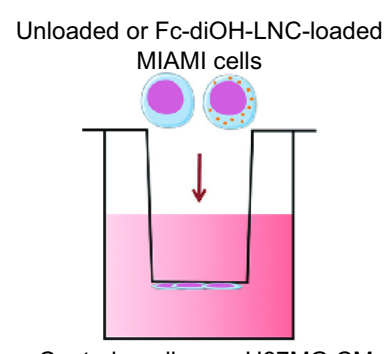

Control medium or U87MG CM

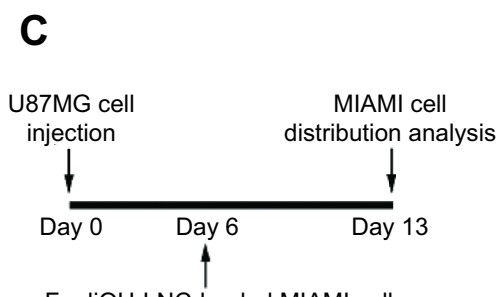

Fc-diOH-LNC-loaded MIAMI cells
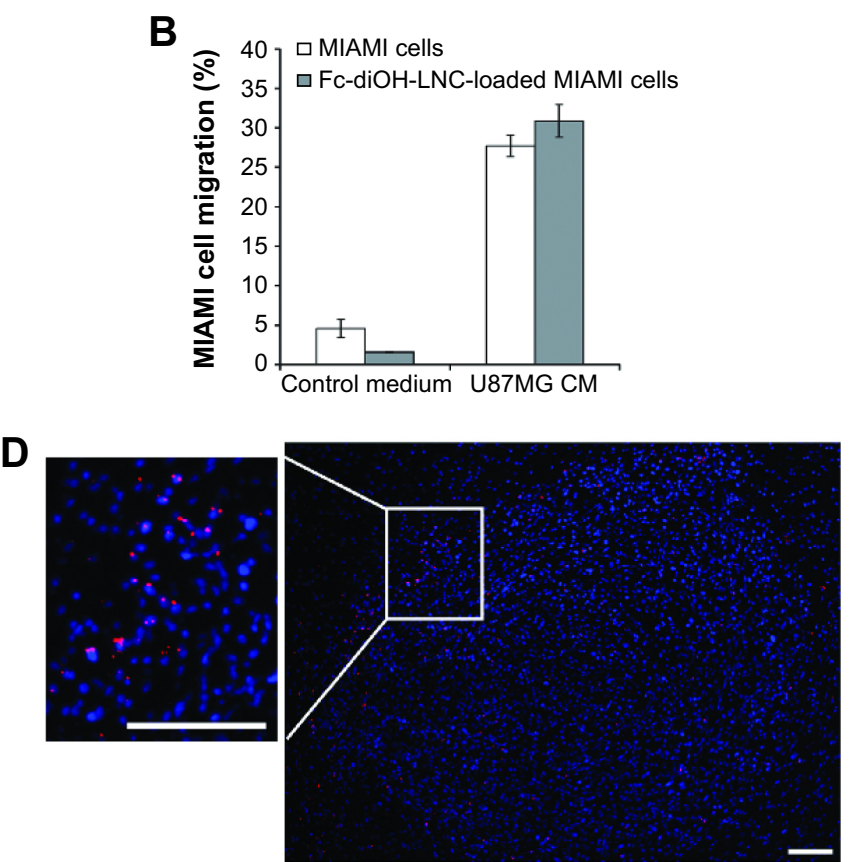

Figure 4 Analysis of Fc-diOH-LNC-loaded MIAMI cell migration toward U87MG cells.

Notes: (A) Schematic diagram of the principle of the migration assay. The pore size of the insert ( $8 \mu \mathrm{m})$ allowed the passage of MIAMI cells. (B) Percentage of unloaded or Fc-diOH-LNC-loaded MIAMI cells migrating, after 4 hours of incubation with the control medium and U87MG CM. The number of MIAMI cells added to the upper compartment was taken as 100\%. Data are expressed as the mean of three wells \pm SEM ( $n=2)$. (C) Schematic representation of the experimental model. (D) Fluorescence microscopy images of tissue sections after the intratumoral injection of MIAMI cells in U87MG-bearing mice. MIAMI cells were detected by labeling the Y-chromosome with a red fluorescent probe. Nuclei were stained with 4',6-diamidino-2-phenylindole (scale bar $=100 \mu \mathrm{m}$ ).

Abbreviations: Fc-diOH-LNCs, ferrociphenol lipid nanocapsules; MIAMI, marrow-isolated adult multilineage inducible; SEM, standard error of the mean; CM, conditioned medium. 
Table 2 Efficacy of Fc-diOH-LNCs and Fc-diOH-LNC-loaded MIAMI cells in the orthotopic U87MG glioma model

\begin{tabular}{lllll}
\hline Treatment & $\mathbf{n}$ & Survival time (days) & IST median (\%) \\
\cline { 2 - 4 } & & Range & 27 & Median \\
\hline Control & 8 & $26-29$ & 26.5 & 29 \\
Fc-diOH-LNCs & 8 & $23-31$ & $26-34$ & $7 \%$ \\
Fc-diOH-LNC-loaded MIAMI cells & 8 & - & 29 \\
\hline
\end{tabular}

Abbreviations: Fc-diOH-LNCs, ferrociphenol lipid nanocapsules; MIAMI, marrow-isolated adult multilineage inducible; IST, increased survival time.

compared only the antitumoral effects of pure Fc-diOH-LNCs and MIAMI cells loaded with Fc-diOH-LNCs. U87MG tumor-bearing mice (tumor volume: $1.15 \pm 0.08 \mathrm{~mm}^{3}$ estimated by MRI) were treated with either Fc-diOH-LNCs or with Fc-diOH-LNC-loaded MIAMI cells, in amounts corresponding to an $\mathrm{Fc}$-diOH dose of $3.6 \mu \mathrm{g} /$ mouse. This dose induces rates of U87MG cell death close to $60 \%$ in vitro. A control group receiving an intratumoral injection of HBSS rather than treatment was also established. The mice of this group survived for up to 29 days, with a median survival of 27 days (Table 2). Fourteen days after treatment, T2-weighted images of control and treated mice indicated that tumor volume was smaller in the group of mice receiving intratumoral injections of Fc-diOH-LNC-loaded MIAMI cells than in the other groups (Figure 5A-C). These mice had a modestly but significantly higher median survival than the mice of the control group. The median survival of mice treated by the intratumoral injection of Fc-diOH-LNCs was no longer than that of the control group (Table 2; Figure 5D).

We characterized the effects of Fc-diOH-LNCs and Fc-diOH-LNC-loaded MIAMI cells on the U87MG tumor in more detail, by assessing their impact on the number of intratumoral $\mathrm{Ki} 67^{+}$proliferative cells and the number of $\mathrm{CD} 31^{+}$vessels 7 days after their injection into the tumor (Figure 6). Treatments with Fc-diOH-LNCs and Fc-diOHLNC-loaded-MIAMI cells decreased the number of Ki67 ${ }^{+}$ proliferative cells within the tumor, and this decrease was significant for the Fc-diOH-LNC treatment. A decrease in the number of $\mathrm{CD} 31^{+}$vessels was also observed for the two Fc-diOH-delivery systems, but this decrease was significant only for the Fc-diOH-LNC-loaded-MIAMI cell treatment.

A

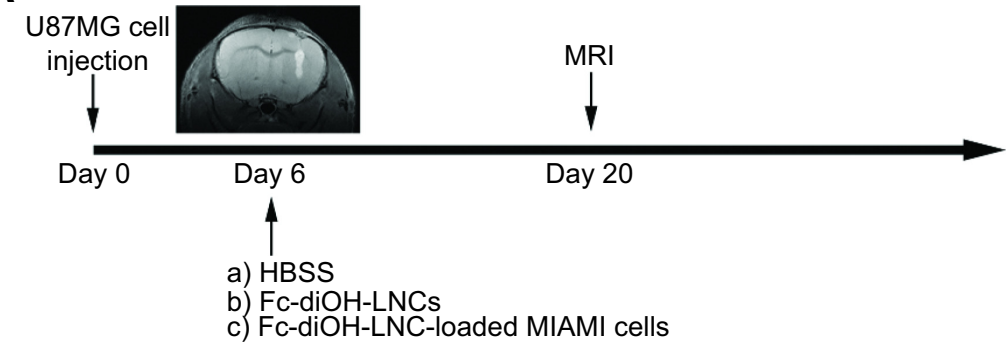

B

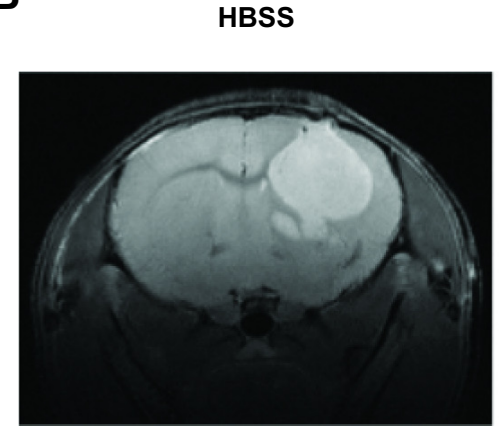

Fc-diOH-LNCs

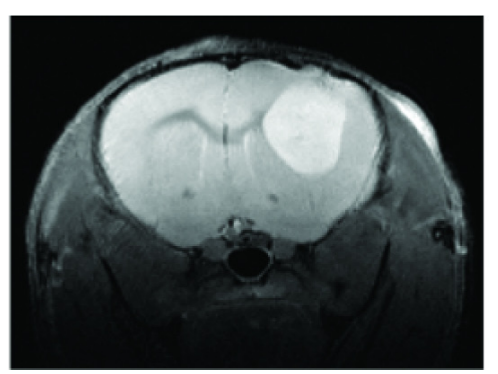

Fc-diOH-LNC-loaded-MIAMI

cells

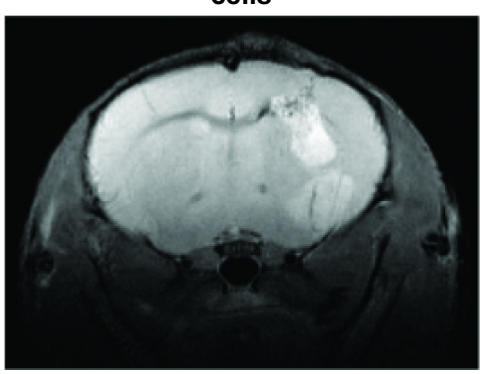

Figure 5 (Continued) 

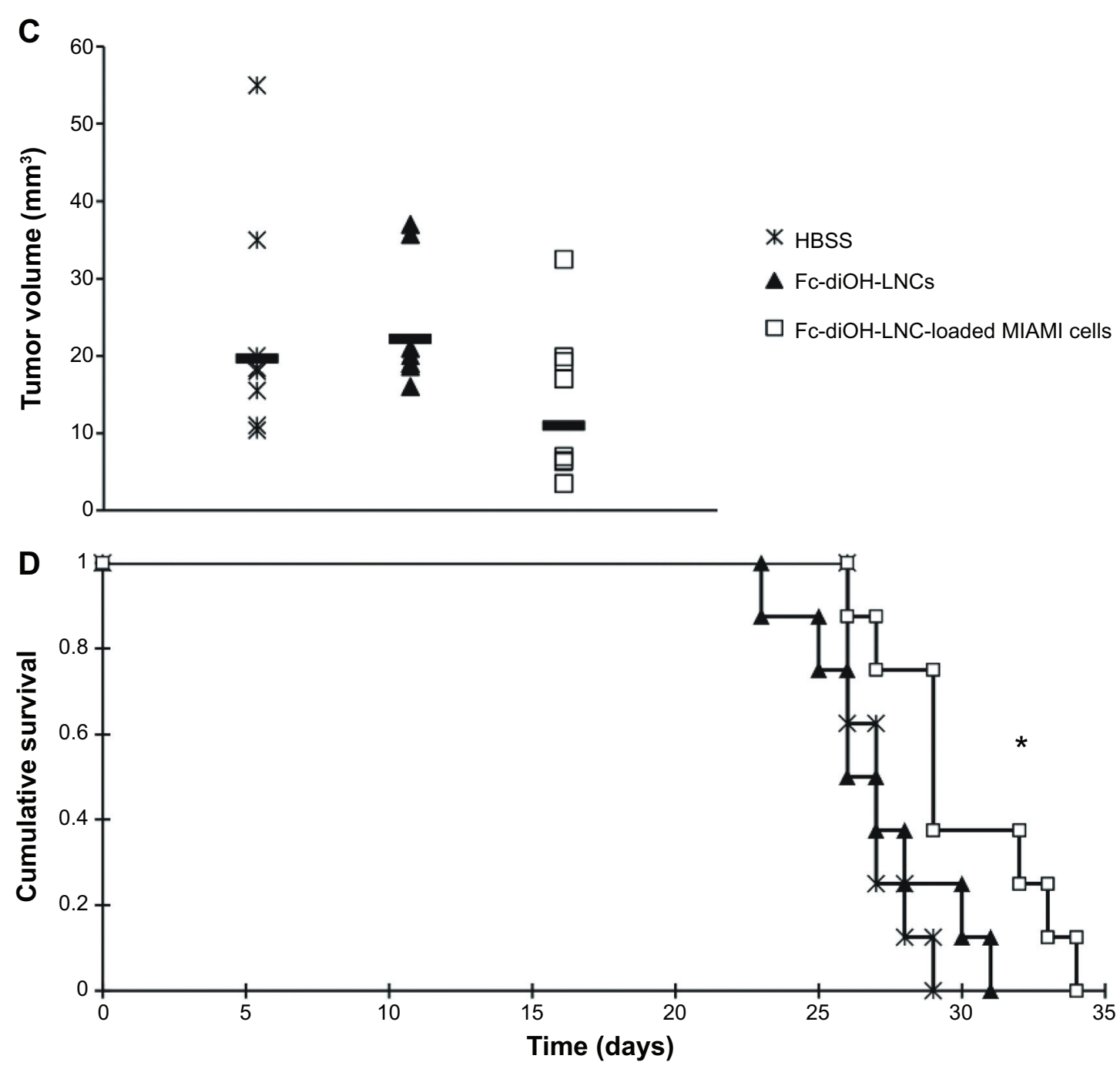

$\rightarrow$ HBSS $\rightarrow$ Fc-diOH-LNCs $\quad \rightarrow \square$ Fc-diOH-LNC-loaded MIAMI cells

Figure 5 In vivo toxicity of Fc-diOH-LNCs and Fc-diOH-LNC-loaded MIAMI cells to U87MG cells.

Notes: (A) Representation of the treatment protocol applied to U87MG-bearing mice. The T2-weighted image shows the presence of the U87MG tumor on day 6, the day of the treatment. (B) Representative T2-weighted images of control and treated mice on day 20. (C) Tumor volume distribution in each group, calculated by MRI on day 20. (D) Kaplan-Meier survival curves for U87MG-bearing mice receiving HBSS, Fc-diOH-LNCs or Fc-diOH-LNC-loaded MIAMI cells, 6 days after the injection of U87MG cells. *Significantly different from the control group $(P<0.05)$ (each group contained eight mice).

Abbreviations: Fc-diOH-LNCs, ferrociphenol lipid nanocapsules; MIAMI, marrow-isolated adult multilineage inducible; MRI, magnetic resonance imaging; HBSS, Hank's balanced salt solution.

\section{Discussion}

MSCs have been studied as a vehicle for cancer gene therapy, ${ }^{5,15,32,33}$ but few studies have addressed the issue of the use of these cells as targeted delivery vehicles for nanoparticles loaded with anticancer agents. ${ }^{6,34-36} \mathrm{We}$ recently demonstrated that MIAMI cells, a homogeneous subpopulation of human MSCs, can deliver Fc-diOH-loaded LNCs, in the subcutaneous U87MG human GB model. In this study, we aimed to demonstrate the potential of MIAMI cell carrier-based targeted delivery, by optimizing the Fc-diOH-LNC-loaded MIAMI cell system and comparing its efficacy with that of free Fc-diOH-LNCs in the intracranial U87MG GB model.

We found that, for the optimal uptake of Fc-diOH-LNCs by MIAMI cells, the concentrations of the LNC matrix components and $\mathrm{Fc}$-diOH should not exceed $1 \mathrm{mg} / \mathrm{mL}$ and $120 \mu \mathrm{M}$, respectively. In these conditions, LC/MS-MS showed that MIAMI cells delivered a dose of about $20 \mathrm{pg}$ of $\mathrm{Fc}$-diOH per cell. The presence of this internalized Fc-diOH in MIAMI cells had no effect on their viability or ability to migrate toward U87MG cells in vitro and in vivo. Furthermore, the cytostatic activity of the Fc-diOH internalized in 


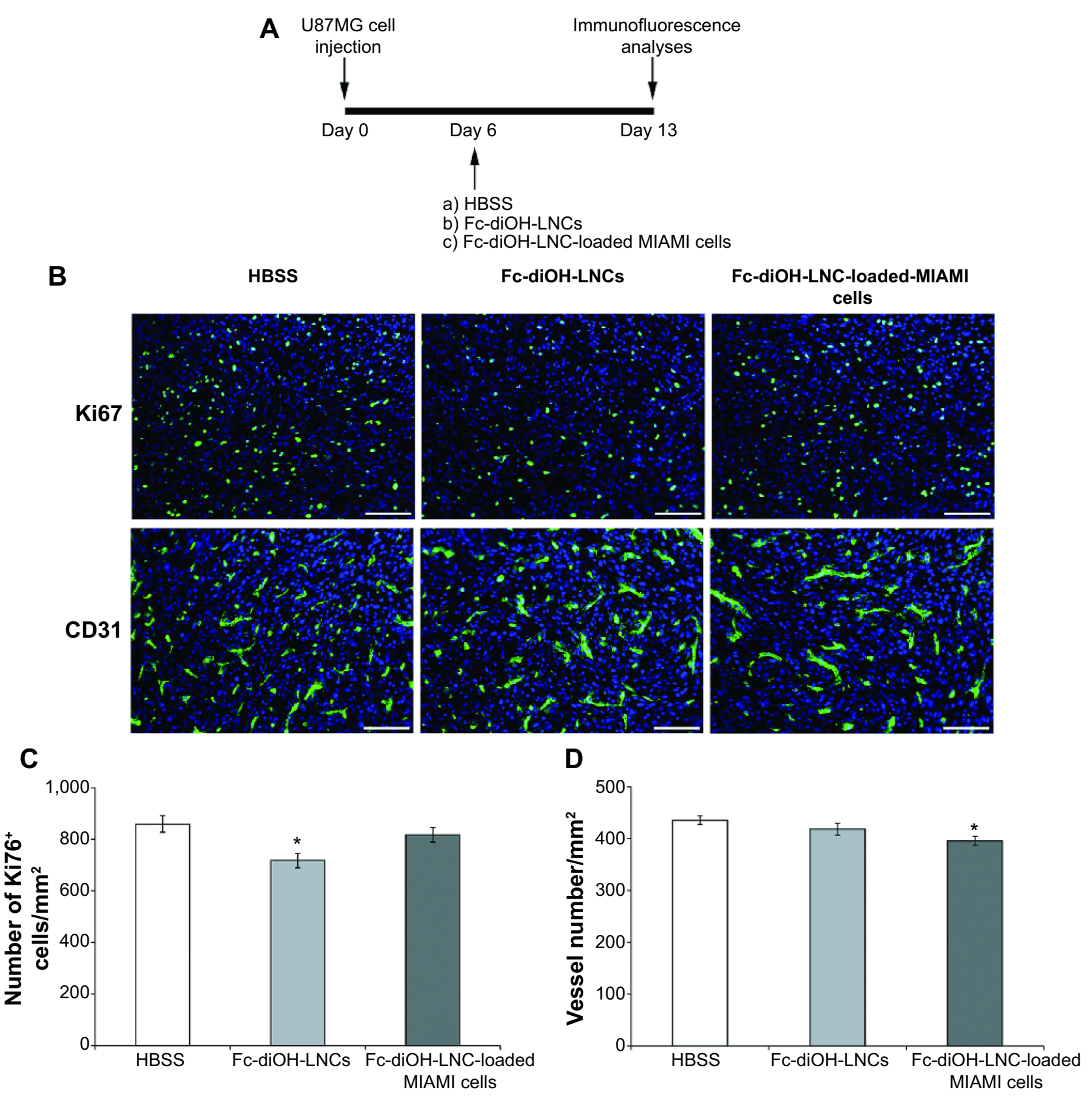

Figure 6 Effect of Fc-diOH-LNCs and Fc-diOH-LNC-loaded MIAMI cells on the number of Ki67 ${ }^{+}$proliferative cells and the number of CD3 I+ vessels present in the U87MG tumor. Notes: (A) Schematic representation of the experimental model. (B) Immunofluorescence staining for Ki67 and CD3I in the tumor 7 days after the intratumoral injection of HBSS, Fc-diOH-LNCs or Fc-diOH-LNC-loaded MIAMI cells (scale bar $=100 \mu \mathrm{m}$ ). (C) and (D) Quantitative results for Ki67 and CD3I immunofluorescence. Results are expressed as the mean \pm SEM number of $\mathrm{Ki} 67^{+}$cells in the tumor $/ \mathrm{mm}^{2}(\mathbf{C})$ and the mean $\pm \mathrm{SEM}$ number of $\mathrm{CD} 3 \mathrm{I}^{+}$vessels $/ \mathrm{mm}^{2}(\mathbf{D})$. $*$ Significantly different from the control group $(P<0.05)$.

Abbreviations: Fc-diOH-LNCs, ferrociphenol lipid nanocapsules; MIAMI, marrow-isolated adult multilineage inducible; SEM, standard error of the mean; HBSS, Hank's balanced salt solution.

MIAMI cells was entirely conserved, resulting in a significant inhibition of U87MG cell proliferation in vitro, similar to that induced by Fc-diOH-LNCs alone. The number of cells required to induce the death of $35 \%$ of the U87MG cells in the coculture experiment was only one sixth that reported in our previous study, ${ }^{6}$ demonstrating the optimization of the amount of Fc-diOH-LNCs that can be carried by
MIAMI cells. The mechanisms by which MIAMI cells excreted Fc-diOH-LNCs and/or Fc-diOH did not involve MIAMI cell death. Further work is required to determine the route by which Fc-diOH leaves MIAMI cells.

The in vitro cytotoxic effect of Fc-diOH-LNC-loaded MIAMI cells was confirmed in vivo, in the orthotopic U87MG GB model. Seven days after the intratumoral 
injection of this Fc-diOH delivery system, a slight decrease in the number of $\mathrm{Ki}_{67^{+}}$cells and $\mathrm{CD} 31^{+}$vessels was observed in the U87MG tumor. This resulted in a decrease in tumor volume 14 days after treatment and a modest but significant increase in median mouse survival over that of untreated mice. This effect was due to the Fc-diOH-LNC loading of the MIAMI cells, because MIAMI cells alone had no effect on U87MG cell growth in vitro and in vivo. ${ }^{6,12}$ The intratumoral injection of Fc-diOH-LNCs also led to a slight decrease in the proportion of $\mathrm{Ki}^{-} 7^{+}$cells and $\mathrm{CD} 31^{+}$ vessels in the U87MG tumor. However, this effect was not sufficient to cause a decrease in tumor volume or an improvement in mouse survival. The greater efficacy of FcdiOH-LNC-loaded MIAMI cells than Fc-diOH-LNCs alone may result from the presence of MIAMI cells at the leading edge of the tumor, a site at which tumor-host interactions, such as angiogenesis and local extracellular matrix remodeling, are very active. ${ }^{37}$ Chemotherapy delivered to this site would be expected to be more potent than chemotherapy delivered to the center of the tumor. MIAMI cell-mediated delivery may also result in better Fc-diOH retention within the tumor environment, constituting another advantage of this cell delivery system over LNCs alone. Consistent with our results, Cheng et $\mathrm{ll}^{38}$ recently reported that intratumoral and contralateral injections of a neural stem cell line loaded with doxorubicin (Dox)-mesoporous silica nanoparticles elicited a significantly stronger therapeutic effect than Doxmesoporous silica nanoparticles alone in the U87MG GB model. Dox was found to be widely distributed specifically within the tumor following the use of this neural stem cell line carrier. Li et $\mathrm{al}^{35}$ also showed that silica nanorattleDox-anchored MSCs tracked down U251 GB cells more efficiently and delivered Dox with a wider distribution and longer retention lifetime in tumor tissues than silica nanorattle-encapsulated Dox.

The increase in animal survival obtained with Fc-diOHLNC-loaded MIAMI cells was similar to that reported for local treatment, by convection-enhanced delivery, with FcdiOH-LNCs, of intracranial 9L gliosarcoma in animals. With our therapeutic tool based on the use of MIAMI cells, an increase in survival was obtained with a dose of Fc-diOH of about $3.6 \mu \mathrm{g} / \mathrm{animal}$, as opposed to the $360 \mu \mathrm{g} / \mathrm{animal}$ reported for the convection-enhanced delivery of Fc-diOH-LNCs. ${ }^{29,39}$ This drug delivery system is therefore very promising for improving the local tissue distribution of drugs in GBs and for limiting side effects.

Despite these promising results, the increase in survival achieved by injecting Fc-diOH-LNC-loaded MIAMI cells was clearly modest. However, this increase in survival was obtained with a single treatment with Fc-diOH-LNC-loaded MIAMI cells, whereas a typical chemotherapy regimen involves the administration of multiple doses over a longer period of time. The distribution pattern of MIAMI cells at the leading edge of the tumor suggests that, in a clinical context, multiple injections of Fc-diOH-LNC-loaded MIAMI cells could be performed, with a handheld syringe, into the walls of brain tumor resection cavities during surgery. We have used this administration route in previous clinical trials for the delivery of 5-fluorouracil-loaded microspheres and adenovirus-mediated gene therapy with sitimagene ceradenovec. $^{40,41}$ The migration of Fc-diOH-LNC-loaded MIAMI cells to the peritumoral zone will kill the residual tumor cells, limiting the risk of recurrence. Furthermore, this therapeutic tool could be combined with external radiotherapy. Indeed, it has been reported that local irradiation may enhance the migration and engraftment specificity of $\mathrm{MSCs},{ }^{42}$ in addition to potentiating the cytotoxic action of Fc-diOH. ${ }^{39}$

\section{Conclusion}

This work confirms the promise of combinations of stem cell therapy and nanotechnology for improving the local tissue distribution of anticancer drugs in GBs. Our results validate the use of MIAMI cells as Fc-diOH-loaded LNC carriers, and we are currently validating the use of this system for the targeted delivery of other toxic agents.

\section{Acknowledgments}

We thank Dr JP Jacob from "la coordination hospitalière des prélèvements d'organes et de tissus" (CHU, Angers, France). We also thank P Legras and J Roux (Service commun d'animalerie Hospitalo-Universitaire, Angers, France), Prof P Schiller (University of Miami School of Medicine, USA), Dr L Lemaire and L Sindji (INSERM U1066, Angers, France) for providing facilities, and Alex Edelman and Associates for correcting the English language of the manuscript.

\section{Disclosure}

The authors have no conflict of interest to declare.

\section{References}

1. Stupp R, Hegi ME, Mason WP, et al. Effects of radiotherapy with concomitant and adjuvant temozolomide versus radiotherapy alone on survival in glioblastoma in a randomised phase III study: 5-year analysis of the EORTC-NCIC trial. Lancet Oncol. 2009;10(5):459-466.

2. Stupp R, Mason WP, Van den Bent MJ, et al. Radiotherapy plus concomitant and adjuvant temozolomide for glioblastoma. $N$ Engl J Med. 2005;352(10):987-996. 
3. Knights MJ, Kyle S, Ismail A. Characteristic features of stem cells in glioblastomas: from cellular biology to genetics. Brain Pathol. 2012;22(5):592-606.

4. Roger M, Clavreul A, Venier-Julienne MC, et al. Mesenchymal stem cells as cellular vehicles for delivery of nanoparticles to brain tumors. Biomaterials. 2010;31(32):8393-8401.

5. Roger M, Clavreul A, Venier-Julienne MC, Passirani C, Montero-Menei C, Menei P. The potential of combinations of drugloaded nanoparticle systems and adult stem cells for glioma therapy. Biomaterials. 2011;32(8):2106-2116.

6. Roger M, Clavreul A, Huynh NT, et al. Ferrociphenol lipid nanocapsule delivery by mesenchymal stromal cells in brain tumor therapy. Int $J$ Pharm. 2012;423(1):63-68.

7. D'Ippolito G, Diabira S, Howard GA, Menei P, Roos BA, Schiller PC. Marrow-isolated adult multilineage inducible (MIAMI) cells, a unique population of postnatal young and old human cells with extensive expansion and differentiation potential. J Cell Sci. 2004;117 (Pt 14):2971-2981.

8. D'Ippolito G, Howard GA, Roos BA, Schiller PC. Isolation and characterization of marrow-isolated adult multilineage inducible (MIAMI) cells. Exp Hematol. 2006;34(11):1608-1610.

9. Roche S, D'Ippolito G, Gomez LA, et al. Comparative analysis of protein expression of three stem cell populations: models of cytokine delivery system in vivo. Int J Pharm. 2013;440(1):72-82.

10. Garbayo E, Raval AP, Curtis KM, et al. Neuroprotective properties of marrow-isolated adult multilineage-inducible cells in rat hippocampus following global cerebral ischemia are enhanced when complexed to biomimetic microcarriers. J Neurochem. 2011;119(5):972-988.

11. Delcroix GJ, Garbayo E, Sindji L, et al. The therapeutic potential of human multipotent mesenchymal stromal cells combined with pharmacologically active microcarriers transplanted in hemi-parkinsonian rats. Biomaterials. 2011;32(6):1560-1573.

12. Roger M, Clavreul A, Sindji L, et al. In vitro and in vivo interactions between glioma and marrow-isolated adult multilineage inducible (MIAMI) cells. Brain Res. 2012;1473:193-203.

13. Nakamura K, Ito Y, Kawano Y, et al. Antitumor effect of genetically engineered mesenchymal stem cells in a rat glioma model. Gene Ther. 2004;11(14):1155-1164.

14. Nakamizo A, Marini F, Amano T, et al. Human bone marrow-derived mesenchymal stem cells in the treatment of gliomas. Cancer Res. 2005;65(8):3307-3318.

15. Hu YL, Fu YH, Tabata Y, Gao JQ. Mesenchymal stem cells: a promising targeted-delivery vehicle in cancer gene therapy. J Control Release. 2010;147(2):154-162.

16. Bexell D, Scheding S, Bengzon J. Toward brain tumor gene therapy using multipotent mesenchymal stromal cell vectors. Mol Ther. 2010;18(6):1067-1075.

17. Bexell D, Svensson A, Bengzon J. Stem cell-based therapy for malignant glioma. Cancer Treat Rev. 2013;39(4):358-365.

18. Huynh NT, Passirani C, Saulnier P, Benoit JP. Lipid nanocapsules: a new platform for nanomedicine. Int J Pharm. 2009;379(2):201-209.

19. Lainé AL, Passirani C. Novel metal-based anticancer drugs: a new challenge in drug delivery. Curr Opin Pharmacol. 2012;12(4):420-426.

20. Vanpouille-Box C, Lacoeuille F, Belloche C, et al. Tumor eradication in rat glioma and bypass of immunosuppressive barriers using internal radiation with (188)Re-lipid nanocapsules. Biomaterials. 2011; 32(28):6781-6790.

21. David S, Montier T, Carmoy N, et al. Treatment efficacy of DNA lipid nanocapsules and DNA multimodular systems after systemic administration in a human glioma model. $J$ Gene Med. 2012;14(12):769-775.

22. David S, Resnier P, Guillot A, Pitard B, Benoit JP, Passirani C. siRNA LNCs - a novel platform of lipid nanocapsules for systemic siRNA administration. Eur J Pharma Biopharm. 2012;81(2):448-452.

23. Griveau A, Bejaud J, Anthiya S, Avril S, Autret D, Garcion E. Silencing of miR-21 by locked nucleic acid-lipid nanocapsule complexes sensitize human glioblastoma cells to radiation-induced cell death. Int J Pharm. 2013;454(2):765-774.
24. Garcion E, Lamprecht A, Heurtault B, et al. A new generation of anticancer, drug-loaded, colloidal vectors reverses multidrug resistance in glioma and reduces tumor progression in rats. Mol Cancer Ther. 2006;5(7):1710-1722.

25. Paillard A, Hindré F, Vignes-Colombeix C, Benoit JP, Garcion E. The importance of endolysosomal escape with lipid nanocapsules for drug subcellular bioavailability. Biomaterials. 2010;31(29):7542-7554.

26. Vessières A. Metal carbonyl tracers and the ferrocifen family: Two facets of bioorganometallic chemistry. Journal of Organometallic Chemistry. 2013;734:3-16.

27. Laine AL, Huynh NT, Clavreul A, et al. Brain tumour targeting strategies via coated ferrociphenol lipid nanocapsules. Eur J Pharma Biopharm. 2012;81(3):690-693.

28. Huynh NT, Morille M, Bejaud J, et al. Treatment of 9L gliosarcoma in rats by ferrociphenol-loaded lipid nanocapsules based on a passive targeting strategy via the EPR effect. Pharm Res. 2011;28(12):3189-3198.

29. Allard E, Huynh NT, Vessières A, et al. Dose effect activity of ferrocifen-loaded lipid nanocapsules on a 9L-glioma model. Int $J$ Pharm. 2009;379(2):317-323.

30. Messina P, Labbé E, Buriez O, et al. Deciphering the activation sequence of ferrociphenol anticancer drug candidates. Chemistry. 2012;18(21):6581-6587.

31. Top S, Vessières A, Leclercq G, et al. Synthesis, biochemical properties and molecular modelling studies of organometallic specific estrogen receptor modulators (SERMs), the ferrocifens and hydroxyferrocifens: evidence for an antiproliferative effect of hydroxyferrocifens on both hormone-dependent and hormone-independent breast cancer cell lines. Chemistry. 2003;9(21):5223-5236.

32. Shah K. Mesenchymal stem cells engineered for cancer therapy. Adv Drug Deliv Rev. 2012;64(8):739-748.

33. Porada CD, Almeida-Porada G. Mesenchymal stem cells as therapeutics and vehicles for gene and drug delivery. Adv Drug Deliv Rev. 2010;62(12):1156-1166.

34. Auffinger B, Morshed R, Tobias A, Cheng Y, Ahmed AU, Lesniak MS. Drug-loaded nanoparticle systems and adult stem cells: a potential marriage for the treatment of malignant glioma? Oncotarget. 2013;4(3):378-396.

35. Li L, Guan Y, Liu H, et al. Silica nanorattle-doxorubicin-anchored mesenchymal stem cells for tumor-tropic therapy. ACS Nano. 2011; 5(9):7462-7470.

36. Gao Z, Zhang L, Hu J, Sun Y. Mesenchymal stem cells: a potential targeted-delivery vehicle for anti-cancer drug, loaded nanoparticles. Nanomedicine. 2013;9(2):174-184.

37. Granot D, Addadi Y, Kalchenko V, Harmelin A, Kunz-Schughart LA, Neeman M. In vivo imaging of the systemic recruitment of fibroblasts to the angiogenic rim of ovarian carcinoma tumors. Cancer Res. 2007;67(19):9180-9189.

38. Cheng Y, Morshed R, Cheng SH, et al. Nanoparticle-programmed selfdestructive neural stem cells for glioblastoma targeting and therapy. Small. 2013;9(24):123-129.

39. Allard E, Jarnet D, Vessières A, et al. Local delivery of ferrociphenol lipid nanocapsules followed by external radiotherapy as a synergistic treatment against intracranial 9L glioma xenograft. Pharm Res. 2010;27(1):56-64.

40. Menei P, Capelle L, Guyotat J, et al. Local and sustained delivery of 5-fluorouracil from biodegradable microspheres for the radiosensitization of malignant glioma: a randomized phase II trial. Neurosurgery. 2005;56(2):242-248.

41. Westphal M, Ylä-Herttuala S, Martin J, et al. Adenovirus-mediated gene therapy with sitimagene ceradenovec followed by intravenous ganciclovir for patients with operable high-grade glioma (ASPECT): a randomised, open-label, phase 3 trial. Lancet Oncol. 2013;14(9):823-833.

42. François $S$, Bensidhoum M, Mouiseddine $M$, et al. Local irradiation not only induces homing of human mesenchymal stem cells at exposed sites but promotes their widespread engraftment to multiple organs: a study of their quantitative distribution after irradiation damage. Stem Cells. 2006;24(4):1020-1029. 


\section{Supplementary material}

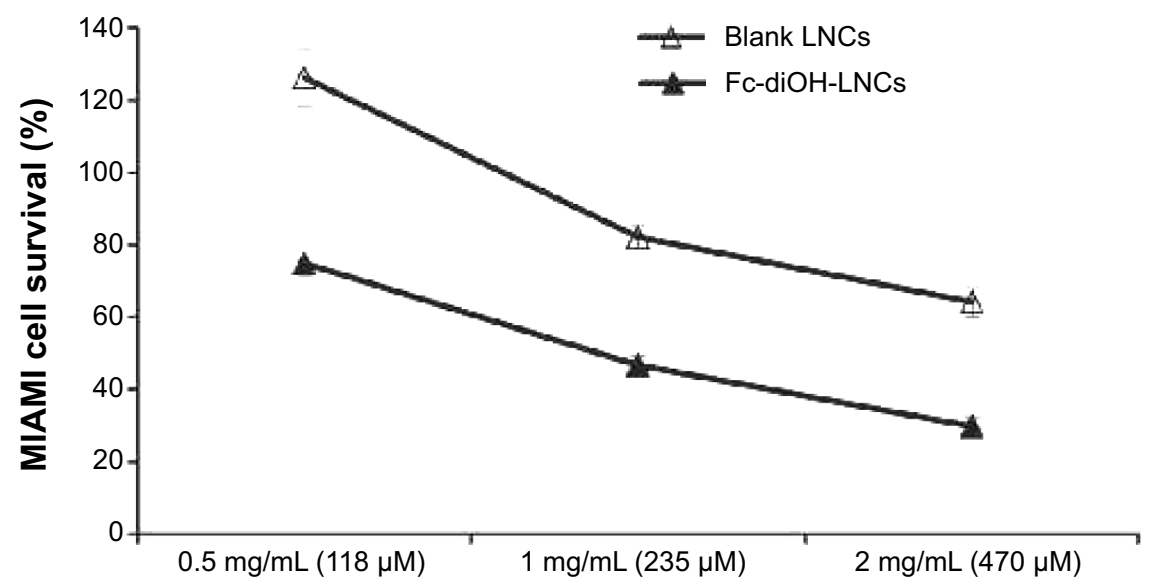

Figure SI Determination of the optimal dose of Fc-diOH-LNCs that MIAMI cells can take up without alterations to viability 7 days later.

Notes: MIAMI cells were incubated for I hour at $37^{\circ} \mathrm{C}$ with three doses of $\mathrm{LNC}$ matrix components $(0.5 \mathrm{mg} / \mathrm{mL}, \mathrm{I} \mathrm{mg} / \mathrm{mL}$, and $2 \mathrm{mg} / \mathrm{mL}) \mathrm{corresponding} \mathrm{to} \mathrm{Fc}$-diOH concentrations of II $8 \mu \mathrm{M}, 235 \mu \mathrm{M}$, and $470 \mu \mathrm{M}$, respectively. For this experiment, a suspension of Fc-diOH-LNCs at a concentration of I 2 mg of Fc-diOH per mL of LNC suspension $(28 \mathrm{mM})$ was used. After uptake, the MIAMI cells were plated in 96 -well plates and maintained in a humidified incubator, under an atmosphere containing $5 \% \mathrm{CO}_{2}$ $\left(37^{\circ} \mathrm{C}\right)$ for 7 days. At the end of this incubation period, cell survival was estimated with the CyQUANT ${ }^{\circledR}$ cell proliferation assay kit (Thermo Fisher Scientific, Waltham, MA, USA), according to the manufacturer's instructions. Maximal fluorescence was determined by incubating unloaded MIAMI cells with the culture medium, giving a value that was considered to correspond to $100 \%$ survival. The experiment was performed in triplicate and the results are presented as means \pm SEM.

Abbreviations: LNCs, lipid nanocapsules; Fc-diOH, ferrociphenol; Fc-diOH-LNCs, ferrociphenol lipid nanocapsules; MIAMI, marrow-isolated adult multilineage inducible; SEM, standard error of the mean.

\section{Publish your work in this journal}

The International Journal of Nanomedicine is an international, peerreviewed journal focusing on the application of nanotechnology in diagnostics, therapeutics, and drug delivery systems throughou the biomedical field. This journal is indexed on PubMed Central, MedLine, CAS, SciSearch ${ }^{\circledR}$, Current Contents ${ }^{\circledR} /$ Clinical Medicine,
Journal Citation Reports/Science Edition, EMBase, Scopus and the Elsevier Bibliographic databases. The manuscript management system is completely online and includes a very quick and fair peer-review system, which is all easy to use. Visit http://www.dovepress.com/ testimonials.php to read real quotes from published authors. 